\title{
The Bible and Gullibility among the Johanne Masowe WeChishanu in Zimbabwe
}

\section{David Bishau \\ ORCID iD: https://orcid.org/0000-0003-2245-4911}

\begin{abstract}
Gullibility takes diverse forms; indeed, it exhibits several dimensions that make it impossible to situate it within a particular discipline and area of study. Religious gullibility in particular is difficult to characterize. One indubitable observation is that it has a psychological disposition, which religious rituals and language so often mystify that the possibility of its occurrence, its exact nature where and when it occurs and its depth and spread are often difficult to ascertain. Therefore, studying it often requires a careful multidisciplinary approach that penetrates its salient features to make a case for its existence and to map its nature, depth and breadth among the devotees of a given religion. This study explored the possibility of the occurrence, nature and depth and breadth of religious gullibility among the Johanne Masowe WeChishanu. The study used the theoretical framework of transactional psychology to analyse ethnographic field notes taken from a case study of the Johanne Masowe WeChishanu in Chitungwiza during the period from 1998 to 2008 in a bid to demonstrate the presence of gullibility in the Johanne Masowe WeChishanu's attitude and overall reception of the Bible. The study's findings are that Nzira, the then leader of the group, played a mind game and instilled among his members a certain attitude towards the Bible. The study's conclusion is that through this mind game Nzira managed to draw attention to himself by removing the Bible from the minds of the devotees and replacing it with his own person. Nzira's psychological stage management obscured gullibility in this case.
\end{abstract}

Keywords: gullibility, sowe, religious ritual, religious language, transaction 


\section{Introduction}

Contrary to the general impression people may have, the Johanne Masowe is not a homogeneous group operating under a unified leadership and structure. This heterogeneity is not unique to the Johanne Masowe, but something that characterises the Apostolic Faith in general (Maguranyanga 2011: vi). There are several almost independent groups known as Johanne Masowe whose only unifying factor is a common ancestry and history (Bishau 2010: 420). For the purpose of this chapter, it was advisable to generally classify these independent groupings into three major groupings in 'Harare', 'Bulawayo' and 'Mutare', respectively, and this distribution is largely historical (Bishau 2010: 420). 'Mutare' here is meant to represent groups in and around Mutare that still meet, at least annually, at the main shrine in Gandanzara. 'Harare' is meant to represent the groups in and around Harare, going even as far as Muzarabani the majority of who are collectively known as the Johanne Masowe WeChishanu (Bishau 2010: 420). Scholars like Musoni and Gundani (2016) carried out research on perhaps a branch of this group, which they refer to as Johane Masowe Chishanu yeNyenyedzi $(2016 ; 2019)$. This implies that the heterogeneity even extends to the individual groupings I earlier stated. I did not have sufficient data on the groups in Bulawayo and therefore I could not make any meaningful analysis of their composition and operations. The conclusion of this article is based on data collected on the group in Mutare and the Johanne Masowe WeChishanu. I selected the group in Mutare for study because of its view of the Bible that is in sharp contrast to that of the Johanne Masowe WeChishanu. Unlike the Johanne Masowe WeChishanu, the Johanne Masowe in Mutare do read the Bible. Therefore, while the focus in this article is on the Johanne Masowe WeChishanu, for clarity, I contrasted it with the Johanne Masowe in Mutare at relevant points in the discussion. I did not study all the groups comprising the Johanne Masowe WeChishanu; I drew my case study from the group led by Nzira, popularly known as Madzibaba Pagineck. This is a group which meets even at present meets, at a Sowe to the North of Makoni Shopping Centre in Chitungwiza, Zimbabwe.

The subject of the Bible among the Johanne Masowe in general has been a subject of research from several and diverse contexts. Researchers have come up with different conclusions about the presence of the Bible among the Johanne Masowe. One group of researchers argues that the Johanne Masowe do not read the Bible. A notable representative of this school is Engelke, who 
describes the founder of the Johanne Masowe, Shoniwa, as the 'Bible burning prophet' (Engelke 2004: 77). Other scholars argue that the Johanne Masowe do read the Bible.

It seems that within their faith, the Johanne Masowe are not in agreement regarding the status and role of the Bible. What is curious is the fact that historically the Bible seemed to have had a central place in the founding 'theology' and traditions of the Johanne Masowe, which some of them, like the groups in Mutare, still maintain. However, the Johanne Masowe WeChishanu have made a radical departure from the traditional Bible-affirming position and there is a need to analyse the factors influencing this radical stance on the Bible closely. Is mere gullibility one of those factors influencing this radical departure from the traditional Bible affirming position?

\section{The Bible among the Johanne Masowe: A Historical Analysis}

A brief history of the Johanne Masowe may be important in an effort to demonstrate the problem under investigation. Officially, the Johanne Masowe movement is known as the Gospel of God Church, although sometimes there are variants to this name like the Africa Gospel Church, which is the name on a preacher's certificate granted to C Sairosi Kutsanzira on 11 November 1960 (Dillon-Malone 1987: 9). In fact, Africa Gospel Church was the first official name of the church adopted at a gathering in Zambia on 14 May 1963, but it was later changed to the current name in 1977 (Dillon-Malone 1987: 9). However, other sources refer to the Church as the Apostolic Sabbath Church of God and the devotees as vaHosanna, especially in the formative years between 1932 and 1947 (Kileff \& Kileff 1979: 151; Anderson 2001: 154).

However, the name of the church does not shed light on the role and status of the Bible among the Johanne Masowe more than some excerpts from the life of the founder do. I cite only a few of the parallels to demonstrate that at its inception the Johanne Masowe Apostolic Church indeed used the Bible.

There are many parallels between some incidents in the Bible and Shoniwa's life. Both primary and secondary sources agree in principle that the founder of the church was John Shoniwa. One informant, who my research assistant interviewed, claimed that members of the Johanne Masowe popularly call him John Phillimon Shoniwa Masowe (Chikanya 2004). The first and latter names were not his names at birth and it is a bit confusing as to how and why members and researchers attached those middle names to Shoniwa's name. 


\section{David Bishau}

According to Chakanya, Phillimon was the person who sewed John Shoniwa's first garment. Dillon-Malone (1987: 19) call him Shoniwa Masedza Tandi Moyo.

The first parallel comes from his mother, Efie's testimony (DillonMalone 1987: 19-20). According to the testimony, Shoniwa's conception was miraculous from the very beginning. When Efie was three months pregnant, the child in the womb began to leap in an extraordinary way (Dillon-Malone 1987: 19-20). Although there was not an equivalent of Mary, the leaping of the child in the womb compares with what took place when John the Baptist did leap in Elizabeth's womb (Dillon-Malone 1987: 19-20). It is not surprising that when he began his ministry Shoniwa called himself John the Baptist. At this time, Efie's husband Jack was in prison in Rusape for refusing to pay tax. When she experienced this extraordinary leaping of the child, she went to Rusape and told her husband, who told her that all was going to be well, but she was not supposed to tell the clergy in her area. The clergy mentioned here were probably either Catholic priests with whom he had a lot of contact or Methodist priests or missionaries with whom, according Murphree, he was quite familiar. What is interesting is that Jack wanted this pregnancy to remain a secret, because if the priests knew about it they would seek to kill the child. This reminds us of how Joseph and Mary took Jesus to Egypt for fear that Herod would kill him. It is important to note from Shoniwa's birth narrative close connections between the legendary births of Johanne Masowe and the biblical figure of John the Baptist. Johanne Masowe alleged he was a replica of John the Baptist.

Another parallel to a biblical tradition is an incident that took place when Efie came back from Rusape. One morning when she was in a field, she began to experience what felt like labour pains. As the pains intensified, she became worried, since the baby was not due yet. She saw a green cloth descending from heaven and she heard a voice commanding her to get hold of this cloth and to kneel down and pray. This reminds us of Peter's experience in Acts that denotes the spreading of the gospel to the Gentiles. Therefore, just as the Peter incident marked the beginning of the spreading of the Gospel to the Gentiles, the birth of Johanne Masowe would mark the spreading of the Gospel to the Africans, in particular, the black Zimbabweans. In her response to the voice, Efie said she did not know how to pray. The voice then taught her the Lord's Prayer. This reminds us of the biblical tradition about how Jesus taught the disciples to pray. It is interesting that to this date, Johanne Masowe 
recites the words of the Lord's Prayer as the voice dictated them to Efie. The prayer is long and detailed, but what is interesting is the substitution of the word 'bread' for 'sadza' in the prayer. Sadza is the staple food among the Shona. It is clear right from conception that Johanne Masowe would be an African apostle of Jesus tasked to preach the gospel to Africans. Efie, the testimony goes, did not tell anyone about this; instead she went to Rusape again and told her husband, Jwho wrote down everything she told him.

One close similarity with the biblical narratives is Shoniwa's call, which I reconstructed from testimonies of two eyewitnesses, Samson Mativera and Onias Bvuma, written on 1 October 1932 and 14 October 1932, respecttively. According to Samson Mativera, the three: Shoniwa, Mativera himself and a Mr Chourombe Mazhambe, were workers at a certain farm (papurazi as farms are commonly known among the Shona) and they were staying in the same room. At this time, people still knew Johanne as Shoniwa. They also nicknamed him Susupenzi, a Shona name for a five-cent coin in the then Rhodesia. The nickname was a derogatory term that referred to a very poor and seriously deprived person. As farm labourers, Shoniwa and his friends were marginalized persons suffering deprivation. However, like a typical prophetic call, his call empowered and raised him to prominence, and was a source of authority that he always invoked throughout his ministry.

One day Shoniwa fell ill. The illness was strange and looked like a mental illness. Using logs, Mativera and Mazhambe secured the door to their room at night so that Shoniwa would not escape at night. On this particular night, the two woke up in the middle of the night, only to discover that Shoniwa had escaped but to their surprise, the door was locked and the logs were as they had fixed them onto the door. They heard Shoniwa speaking to someone outside, who, according to the two witnesses, was Satan. As was the case with Jesus' temptations, Satan was offering Shoniwa everything in heaven and on earth on condition that Shoniwa would worship him. Shoniwa refused saying, 'Get behind me Satan!' This happened for some time, with Shoniwa giving the same reply. Satan left him for some time and then came back and then said to Shoniwa, 'I have come to take back my sins from you. I have removed four ten-cent coins from one of your sides'. Still Shoniwa told Satan to leave him alone. After this incident, Shoniwa knocked on the door and Mativera and Mazhambe let him in. He was cold, breathing heavily and showing every sign that he was seriously ill. According to Mativera, Shoniwa died early in the morning before sunrise. 
At sunrise, Mativera says they heard a voice, which they believed was God's voice, calling Shoniwa from heaven. According to Mativera, God called Shoniwa three times, using his nickname. This shows close parallels with Samuel's call. When God called Shoniwa, he answered, 'You are Lord. Be gracious to me'. Mativera says Shoniwa's body was in the room, but they heard his voice as if it were in heaven. The voice from heaven then instructed Shoniwa to sing a song, 'Be gracious to us Lord! Alleluya! Alleluya!' that is a popular song among the Johanne Masowe to this day. In the ensuing conversation, Mativera says God told Shoniwa that he was ill because of his sins from birth. God wanted to take Shoniwa now, for there was a task God wanted him to do. However, Shoniwa pleaded with God to take him back to the earth where there were more people. God then allowed him to return to earth and, according to Mativera, immediately Shoniwa came back to life. His first words were,

People of this world are in pitch darkness. Did you listen to me speak with the Father. God wanted to give me work to do in heaven but I requested God to allow me to come back here on earth so that I can teach people here.

This is a typical example of an Old Testament prophetic call narrative. However, the Johanne Masowe contextualize the Old and New Testament conceptions of theophany and commission based on their understanding of Shona spirit mediums. Johanne, like all Shona mediums, fell ill, which usually is a sign that some important external force wants to possess a person, but unlike the spirit mediums among the Shona, Johanne saw visions of the New Jerusalem. We witness here a key characteristic of the Johanne Masowe 'theology' and modus operandi. The Johanne Masowe do not put in writing inherited biblical traditions, but rather they become part of, and are acted out in, a contextualized apocalyptic drama. This dramatization comes out more clearly among the major group that this study focuses on, the Johanne Masowe WeChishanu, who claim that the Bible is present among them, as Engelke puts it, 'live and direct' (Engelke 2004: 77).

During the same incident, God gave Johanne the Ten Commandments. Again, we witness a contextualized version of the incident at Mt. Sinai where God gave Moses the Ten Commandments. It is interesting that some sections of the Johanne Masowe refer to Johanne as the Black Moses. It is interesting 
that while the commandment regarding the Sabbath is surprisingly absent here, it is crucial to note that right from the beginning keeping the Sabbath is a key commandment among the Johanne Masowe. However, one group observes Saturday as their Sabbath day, while the Johanne Masowe WeChishanu observes Friday as their Sabbath.

Other close parallels to biblical traditions are events about Johanne's death and resurrection that Onias Bvuma recorded on 14 October 1932. These events are key elements of Johanne's call that eventually led to Johanne's ministry from Mount Marimba. I will not give all the details that Bvuma recorded, but Johanne fell ill after falling off from a bicycle. Johanne lit seven candles in his hut (Sundkler \& Steed 2000: 970). This is one very crucial incident, which seems to be a dramatization of Revelations 4: 5. It is important to note that this verse is on the official stamp and logo of the Gospel of God Church and is clearly inscribed with the picture of the golden stand with its seven candles lit and standing on the whole globe. The latter imagery implies that Johanne, while focusing on Africa, conceived of his mission as a universal one.

Johanne died at 1 o'clock in the afternoon and the white farmer who was his employer asked his workers to collect the body and bury it around 4 o'clock the same day. The workers could not finish digging his grave and could not bury him since it was late. Therefore, they put the body in the grave and put metal sheets on the grave hoping to bury the body the following day. Bvuma narrated something dramatic that happened the following day.

At 7 o'clock, the workers went to the grave to complete the burial process and they were shocked to discover that Johanne's body was not there. They told the owner of the farm who probably took it lightly and simply said he was going to report the matter of a missing body to the police, a thing he probably did. According to Bvuma, when Johanne rose from the dead he went up Mount Marimba near Hunyani River. Nobody witnessed the resurrection, but Bvuma and the other workers saw Johanne the following day in the mountain and he was singing a song called 'Hosanna'. This has become a key song of the Johanne Masowe and a definitive mark of their identity.

According to Johanne's own testimony, a man appeared and took him to heaven. When the two approached the first gate, they saw a man who called himself Abraham. It is important to note that Abraham occupies a very important place in the Johanne Masowe theology and there are songs formulated around the figure of Abraham. Abraham opened the gate and Johanne and his 


\section{David Bishau}

escort entered. They approached the second gate manned by Isaac and a third one manned by Jacob. Again, it is vital to note that the patriarchs occupy a very important place in the theology of the Johanne Masowe and socially the Johanne Masowe organize themselves along patriarchal lines. When the two were at the third gate, Johanne says, he heard voices of people wailing and crying and he became afraid. Jacob opened the gate and they entered. At this point Johanne narrated something with very close parallels to John's vision in the book of Revelations. He saw a big river as glorious as the sun, with people that he could not count, so full of joy that Johanne felt a burning desire to be part of them; the city was so glorious that he felt a burning desire to be its citizen.

When Johanne approached the river, he came across Peter with two other men. One of the two must have been Jesus, who told Johanne that he did not allow anyone to enter the city unless they were baptized. Again, note the parallels with John 3. Johanne stepped into the river and Jesus came and grabbed him by the hand. Immediately a crowd of infants, that Johanne later discovered were born as twins, came to the river. Apparently, these infants came from the traditional Shona society where Johanne belonged. The traditional Shona society considered it a bad omen to give birth to twins, or a disabled child, or an albino. These were common grounds for divorce and sometimes excommunication from society. Therefore, Shona women would get rid of such children at birth and culturally the society expected of them to do so. The infants suffered cruel deaths. The women would either burn such unwanted infants in fire or suffocate them in huge clay pots. Johanne learnt that the early Shona people had killed these infants.

Johanne says the infants asked Jesus when the world would end so that their fathers would receive their due judgement and punishment for their crime. Jesus comforted them, saying it would soon do something. Jesus gave them white robes and they left. Immediately another group of infants and children who had died through acts of witchcraft came. These came crying, demanding to know from Jesus why their communities in Africa had killed them. Angels around Jesus suggested it was better somebody from among the Africans was sent to the Africans because they were now very evil. Jesus then baptized Johanne and commissioned him to go back to Africa with a message that they should repent from witchcraft, as the world was about to end. There Jesus gave Shoniwa the name of John the Baptist, for he was going to preach to Africans and baptize them. The missionary churches had failed to teach the Law among the Africans. They had failed to address African problems. Again, Jesus told 
Johanne to sing 'Hosanna' and another song 'Mweya Mutsvene' (Holy Spirit). Angels then escorted Johanne through the gates back to earth. He found himself standing by the grave and beside him, was a rod, a white gown and a small Bible. He took these three items and went up Mount Marimba. These became Johanne's key tools for ministry.

From this brief background to his prophetic call, it is clear that the founder of the Johanne Masowe movement was closely associated with, operated within the understanding, and based its teachings on the Bible. From the call, Johanne made a series of prophecies and pronouncements. The prophecies were compiled in a book entitled Izwi RaMwari MuAfrica (translated as 'Prophecy of God in Africa') 1932. On pages 9-13, Johanne describes several trips that his followers must embark on. On page 11 is a trip to England and the purpose of the trip is to go and retrieve the three items mentioned above, the rod, gown and Bible. According to Madzibaba Mundonga (2005), the Johanne Masowe strongly believe that the three items are stored in a library in England.

However, what is more fascinating as far as it takes us deep into the book of Revelations is the Johanne Masowe's view of the New Jerusalem. The Johanne Masowe took a group of women referred to as the 'sisters' as the New Jerusalem. Johanne Masowe recruited them as virgins and the women took vows not to get married to keep themselves pure (Mundonga 2005). The Johanne Masowe sometimes regard sisters as the Ark of the Lord where Moses placed the Book of the Covenant (Izwi RaMwari kuAfrica 1932: 1). However, the key imagery comes from the book of Revelation. According to the same source '... Mwari ndiyezve akati Mai Meggie ndiro Jerusarema remuAfrica ...' (God is the one who ordained Meggie to be the Jerusalem of Africa). Meggie is mbuya Matanhire, the founding leader of the sisters and in fact the de facto leader of the Gospel of God Church (Mundonga 2005).

Johanne's vision of the virgins was that they would be vessels of the Holy Spirit. There are clear instructions to support these sisters materially as the New Jerusalem of Africa and the Masowe strongly believe that when Johanne recruited the virgins in a typical Mosaic fashion recorded in Numbers 11, his spirit rested on them. Similarly, when he died, his spirit remained with them. Thus, the Johanne Masowe consider the sisters both as the embodiment of the Law and as the vessels or embodiment of the Holy Spirit. The Johanne Masowe WeChishanu call them Vamiriri veMweya (representatives of, or those who stand in for, the Holy Spirit). 
It is clear that historically, the Bible takes centre stage among the Johanne Masowe. It still does among the Johanne Masowe in Mutare. It is in this context that I find Engelke's depiction of Johanne Masowe as a Bibleburning prophet (Engelke 2004: 77) unattainable. Maybe Engelke's conclusion arises from the fact that he based most of his studies of the Johanne Masowe on one group, the Johanne Masowe WeChishanu, who openly claim that they do not read the Bible. According to them 'Bhaibheri munya', or 'Bhaibheri chitunha'. I discuss this in detail later in my analysis section. It may be interesting to check how and why the Johanne Masowe WeChishanu adopted this view of the Bible against the assertive presence and role of the Bible that we observe from the history of the movement. What could be the factors that influenced the Johanne Masowe WeChishanu to depart from their founder? Why do they differ from the Johanne Masowe in Mutare with regard to the presence and use of the Bible among them? Does the physical non-availability of the Bible among the Johanne Masowe WeChishanu mean the Bible is really absent among this group? How are we to account for this apparent denial of the relevance of the Bible? To what extent can we explain this in terms of gullibility among the members?

On one of my visits to their main shrine in Chitungwiza, I made two interesting observations. First, most of the leading Vadare (the late Madzibaba Nzira's lieutenants) among the Johanne Masowe WeChishanu were once members of either some established missionary churches or Pentecostal churches like ZAOGA. Therefore, they must have been familiar with the Bible one way or the other. Furthermore, most of the prophecies uttered on that day were biblically based. For example, one prophecy that narrated a huge rock falling down reminds one of Jesus' remark in Luke 10: 18. Besides, the late Madzibaba Nzira, the leader of this group, referred to various biblical figures and considered himself possessed by the spirit of Abraham and sometimes the spirit of Moses. He also claimed baba Johanne's spirit was often upon him. When he spoke in spirit, he repeated baba Johanne's mission to Africa. Therefore, how are we to understand the Johanne Masowe WeChishanu claim that they do not read the Bible? Does it mean the Bible is absent among them? Can we explain this absence in terms of gullibility on the part of the members of the Johanne Masowe WeChishanu? I chose Eric Berne's analytic model of Transactional Analysis (TA) that has its roots in psychology and psychotherapy to explain the presence or absence of the Bible among the Johanne Masowe WeChishanu. 


\section{Transactional Analysis (TA) as the Model of Analysis in this Study}

In this article, I chose to probe the questions above through the model in psychology called Transactional Analysis (TA). A Canadian-born United States psychiatrist, Eric Berne developed TA in the late 1950s (Widdowson 2010:9). He developed the concept in a series of articles (Berne, 1957a; 1957b, $1958 ; 1959$ ) and in several books (Berne 1961; 1963; 1964; 1975a; 1975b). TA became subject of discussion from that time to the 2000's when new ways of reading and understanding Berne led to a series of papers, most of which were by Cornell (2000 and 2005), Tudor (2002), and Cornell and Landaiche (2006). In this decade, major books on TA include those by Widdowson (2010), Lapworth and Sills (2011), Cornwell, Graaf, Newton and Thunnissen (2016), Widdowson (2016) and, very recently, Cornwell (2020).

TA is both an approach to the psychological and psychotherapeutic theory that integrates elements of humanist and cognitive psychoanalysis and a theory of communication. As a psychoanalysis theory, it describes first people's psychological structure using the psychological model borrowed from Freud's theory of the human psyche. As a theory of communication, TA looks at how a person's personality affects communication and the resultant impact of the communication on that person's interactions with others.

While TA has its roots in psychoanalysis, Berne marked a point of departure from psychoanalysis by focusing more on transactional analysis than on psychoanalysis per se. Through TA, Berne introduced a paradigm shift from the traditional psychological and psychotherapeutic belief that increasing awareness of the contents of unconsciously held ideas brings healing to a patient. Berne's TA drew people's attention to the content of people's interactions with one another and the basic belief that changing these interactions would bring healing through solving the patient's emotional problems. Thus, Berne focused on both understanding and curing his patient by pursuing specific desirable changes that brought healing in the patient.

Berne revisited Freud's theory of the human psyche as comprising the id, ego, and super-ego. Berne zeroed in on the ego and further subdivided it into three more states, which he referred to as 'ego states' namely the Parent, Adult, and Child states (Cornwell et al. 2016: vii). According to Berne, childhood experiences largely shape these ego states. Bad experiences at childhood bring harm to a person's Adult and Parent ego states, resulting in 


\section{David Bishau}

unproductive interaction (transactions) with other members of the community.

The diversion to phenomenology that Berne introduced to his TA, following the influences of psychoanalysts like Federn, Weiss and Erikson (Heathcote 2010: 257) fascinated me and attracted me to TA. In fact, his definition of an 'ego state' was indeed a phenomenological one. According to Berne (1961:17), an 'ego state' from a phenomenological perspective is

... a coherent system of feelings related to a given subject, and ... a set of coherent behaviour patterns; or ... a system of feelings which motivates a related set of behaviour patterns.

In that score, he identified common counterproductive or ineffective social interactions that he referred to as 'games' (Cornwell et al. 2016: 86). I am a little bit uncomfortable with terms like 'counterproductive' or 'ineffective' to describe the 'games'. I follow Berne and his school in their focus on social interaction from a phenomenological perspective. Berne utilized phenomenology to explain his concept of identification. By this concept, Berne refers to the process of identifying from which type of ego state a person may be transacting at any given time (Lapworth \& Sills 2011: 29). Berne found phenomenology useful to diagnose transactions, due to the ego state of a person subjectively re-experiencing the past; that is, experientially reliving the original event (Lapworth \& Sills 2011: 31).

Phenomenology too is my point of entry into the identification (diagnosis) and analysis of the types of ego states that Nzira and his members transacted from in their communications about the Bible. However, I mark a point of departure from Berne and his school who used identification within the context of psychotherapy. I focus on how Nzira, a powerful and advantaged religious practitioner, manipulated and/or abused transactions to produce negative behaviour among innocent but gullible members of his sect. I elaborate on this later below. Therefore, although in the history of the interpretation of TA there have been marked references to, and comparisons with Freud's developmental stages - oral, anal, phallic, and Freud's three ego states - id, ego and superego. I refrain from such marked references and comparisons, since I do not want to turn this article into a psychological treatise featuring Nzira and his devotees. I only refer to Freud and certain details of Berne's TA, where I think such a reference may clarify my discussion of Nzira's personality and the transactions between him and his devotees. 
To understand how I use TA as a phenomenological approach, there is a need to discuss those key elements of the approach that are useful for my analysis very briefly. The key concept that many scholars regard as the cornerstone of TA is that of ego-states (Berne 1972: 223; Heathcote 2010: 254; Widdowson 2016: 10). An ego state is a way in which a person thinks, feels and behaves that defines and/or manifests that person's personality at a given time. As I stated earlier, from a phenomenological perspective, Berne (1961: 17) defines an ego state as a system of feelings that motivates or triggers a related set of behavioural patterns. This is my preferred definition because of my focus. I look at the possibility that Nzira packaged his feelings about the Bible in a way that manifested a 'parent figure' that triggered a behavioural pattern among his church members of rejecting the Bible as stale. Thus, the concept of ego states is critical for my analysis. It is prudent at this point to say a little more regarding the three 'ego states'.

As I hinted earlier, Berne did not coin the term 'ego' or 'ego state'. Rather, he developed a point of departure in the ego state theory from Freud, but more so from Weiss (1950), Federn (1952) and Fairbairn (1952), his contemporaries (Widdowson 2016: 10). Berne identified three 'ego states', namely the child, adult and parent ego states, respectively, and outlined four ways of diagnosing them as behavioural, social, historical and phenomenological (Berne 1961: 76).

The Parent ego state refers to the coherent system of feelings, thoughts and behaviours that are either copied and/or borrowed, or even learned from a parental figure (Berne 1961: 66; Widdowson 2016: 10). The parental figure is not necessarily the biological parent, but a significant other who wields enough power, authority or influence to trigger or motivate a related behavioural pattern in people assuming a Child ego state (Berne 1961: 66; Cooke 2019).

The Adult ego state, like the Parent ego state, is a coherent system of feelings, thoughts and behaviours that manifest a personality who operates rationally, logically and appropriately without external influence in the here and now (Berne 1961: 67; Cornwell et al. 2016: 5).

The Child ego state is an archive, as it were, of those feelings, thoughts and behavioural patterns experienced from childhood (Berne 1961: 69; Morad 2018). These feelings, thoughts and behaviour patterns from the past lie in the subconscious, or what Adams (2008: 4) calls 'a person's unconscious state', and only a Parent figure triggers or activates them at an appropriate time. Thus, a person operating within the Child ego state does not necessarily behave as a 


\section{David Bishau}

child, but brings to consciousness some childhood experiences the moment a Parent ego state activates them through a transactional stimulus.

Berne's ego state theory is much more than what I am presenting here. Berne did much more in a bid to carefully process his thoughts and sharpen his therapeutic profession using TA. For example, he used capital letters as I did above to show the difference between the theoretical Parent, Adult, and Child ego states from adults, parents, and children in real life and he provided detailed and refined explanations for his selection of each of his concepts. However, in principle, Berne based his TA on three axioms, which Morad (2018) neatly summarises as follows:

- Every person has three 'ego states' (Parent, Adult, and Child);

- At any given time, individuals communicate from a particular ego state, either internally with themselves, or with other people and Berne refers to these intra-personal or interpersonal communications as transactions (Berne 1961; see also Widdowson 2016: 12);

- During the interpersonal communications, individuals unconsciously activate their ego states, which can lead to either negative emotions or pain in, or conflict with, others.

As such, a number of scholars and practitioners from various disciplines have used TA for different purposes. Berne used it in the area of psychotherapy. However, in essence, the scholars and/or practitioners utilize a key concept of TA to analyse contaminated communication between two or more parties in a bid to identify sources of either negative emotions or pain in, or conflict with, others. The key concept is, by identifying which ego states the parties are transacting from the scholars and/or practitioners may gain better insight into human psychosocial relationships and the insight may assist in prescribing remedial action where the ego states have caused negative emotions or pain in, or conflict with, others.

Later TA theorists refined Berne's ego-state theory. For example, TA theorists in Australia argued that there is need to place the Adult ego state within the Parent ego state (White 2000: 4). Only two ego states are significant when analysing communications between parties. Thus, the Australian TA theorists restructured Berne's three ego-state theory into a two ego-state theory.

The Adult ego state does not quite fit into my scheme of analysis and 
it is for this reason that I adopt the two-ego-state proposal from Australian TA practitioners, which is useful when clarifying the three types of transections and the kind of Games Nzira was playing. Thus, the two ego-state theory attracted me and I used this revised version of Berne's ego state theory in my analysis. This is my second point of departure from Berne.

Berne viewed communication and/or interactions between two or more parties in their respective ego states in terms of transactions. Most scholars and/or practitioners in TA define the term transaction as the flow of communication, and more specifically the unspoken psychological flow of communication that runs in parallel between the transacting parties at both explicit and psychological levels (Negi 2010: 427). Berne preferred to use the term 'transaction', as opposed to communication or interactions to emphasise the fact that in communication and interactions people invest something of themselves in communication, expecting a return in their investment (Cornwell et al. 2016: 60). This is the point that I utilize in this article to analyse the kind of investment that Nzira put in his communication with his members and the return on the investment he expected from the communication.

One of the points that Berne emphasised was that during communication or transactions, the parties involved can contaminate these ego states. Berne's focus was on developing ways to heal his clients by improving communication and therefore his emphasis was on avoiding contamination of ego states. My focus is elsewhere.

In this article, I mark my third point of departure from Berne in that I analyse Nzira's deliberate contamination of ego states through manipulation of the ego states to achieve some expected return on investment in his communication with members. Nzira's desired return on investment comes out clearly in my analysis of field observations below.

\section{TA and Analysis of Data from the Field}

I based my analysis on specific concepts of TA that explain various ways in which Nzira contaminated the ego states from which he and his members transacted. Thus, the concept of contamination is the overarching conceptual framework for analysis. The other concepts complement my analysis of the transactions between Nzira and his members from within the context of the contamination of ego states. I explain these other concepts, as I do the analysis for purposes of exercising the economy of both space and time. These concepts 


\section{David Bishau}

are reciprocal, crossed and duplex transactions respectively, strokes, mythos and its role in reinforcing a person's life script, redefining and discounting, and time structuring through ritual, games and intimacy. However, it is prudent to briefly explain contamination as the overarching analysis framework.

All scholars on TA define contamination as a concept and each scholar has particular emphases, depending on their peculiar research focuses. I was particularly attracted to Melwin (2014)'s explanation and especially his examples, because they suit exactly my specific focus in this analysis section. According to Melwin (2014), we experience contamination of ego states when the parent intrudes into the boundary of the child ego state. The reverse is also true when the child ego state intrudes into the boundary of the parent ego state. For example, there is contamination in transactions if an adult accepts as true either distorted or unfounded parent beliefs (Joy 2014). This is adult contamination (Martin 2011:597). Similarly, there is contamination in transactions if an adult either mistakes some parental slogans as adult reality or takes some taught beliefs as facts (Joy 2014). This is child contamination (Martin 2011: 597). As I demonstrate in the analysis section of this article, child contamination comes out as gullibility on the part of the members of Johanne Masowe WeChishanu. It becomes even clearer as gullibility, taking into consideration Martin (2011)'s additional explanation. Martin (2011: 597) adds that child contamination results in delusions grounded in fear and her point applies in the three cases I selected for analysis.

I have already defined the term 'transaction' in detail above. In this analysis section, I now want to look at the different types of transactions within the context of the rest of the concepts of TA, which I identified earlier. From my ethnographic field notes on the Juranfiri Santa (place of healing), a congregation of the Johanne Masowe WeChishanu, led by the late Madzibaba Pagineck or Godfrey Nzira, I selected only three cases, which I name Case 1, 2 and 3, to demonstrate my thesis in this article well. These are field notes I took in 1999 at the Juranfiri Santa when I was doing field research for my doctoral study. I visited Nzira's shrine almost every day. During most of my visits I accompanied Matthew Engelke and his fiancé (I hope I understood their relationship well) Rebecca Nash, two very accomplished anthropologists who, consciously or unconsciously, taught me many skills on how to do field research. Besides, Matthew had a car, a Mazda 323, and I had none. I am very grateful to him because the availability of ready transport increased my frequency at the shrine. 


\section{Analysis of Case 1}

The first occasion was an incident involving a man who probably was not yet an established member of the Johanne Masowe WeChishanu. This I deduced from the fact that like us he was not clad in the expected Johanne Masowe regalia. However, from his testimony he must have received healing from Nzira and he had come to express his gratitude. In his expression of thanks, he cited from the gospel of Luke in the New Testament. Immediately, as if incensed, the Vadare who were close to him instructed him to sit down. Nzira suddenly appeared from nowhere and started preaching in a very dramatic way. He explicitly castigated this man for citing from the Bible.

Pano hatitauri nezvemaBhaibheri. Chii Bhaibheri kwandiri. Bhaibheri rinoita munya. Inga mukarichengeta rinomweka. Ramweka motora mapepa acho moashandisa mutoireti. Pano tine Bhaibheri rechokwdi. (We do not talk of Bibles here. What is the Bible to me? It gets stale. After keeping it for a long time, it falls apart and you use the loose papers from it as toilet paper. Here we have the true Bible.)

I then understood that this was the source of the Johanne Masowe WeChishanu's 'slogan', Bhaibheri munya or Bhaibheri chitunha. Engelke (2004)'s statement, 'Bhaibheri rinogara', literally meaning 'the Bible stays', does not quite bring out the actual metaphorical meaning of this statement. The first statement can be translated literally as 'The Bible is stale, i.e. sadza that has stayed overnight' and is thus no longer hot, while the second statement literally means, 'The Bible is a corpse', meaning it is dead; it has no life. The metaphorical meaning is that the written Bible has overstayed its usefulness and it is thus no longer relevant.

To analyse and draw meaning from the transactions at play during this first case, there is a need to take cognizance of different types of transactions in TA. Generally, TA scholars recognize three kinds of transactions, namely Reciprocal or Complementary, Crossed and Covert transactions, respectively.

A reciprocal transaction occurs when both partners address the ego state; the other is to complement the transactions. In this kind of transaction, there is a psychologically balanced exchange of strokes. The parties in the transactions pay one another attention. In this first case, Nzira was careful to avoid this kind of transaction. He decided to castigate the man in a sermon. 


\section{David Bishau}

Devotees do not answer or raise questions during a sermon. In a way, communication during a sermon is one-way and not reciprocal. The man remained glued to the ground, perhaps wondering what he had done wrong. In my analysis, Nzira discouraged reciprocal transaction here, because it would undermine the assumption and perpetuation of his Parent ego state among his members.

Crossed transaction occurs when one partner in the transaction addresses an ego state other than that their partner is in, resulting in communication failure. This type was not present in this case and I never witnessed this type of transaction at the Juranfiri Santa. Communication between Nzira and his members was very clear and each party was fully aware of their ego states during the communication. In cognizance of their Child ego state, the Vadare ordered the man to sit down, just as children do when one of them does something wrong to a parent.

The third type, the covert transaction, was the most common type at the Juranfiri Santa. A covert transaction takes place where the explicit social conversation occurs in parallel with an implicit psychological transaction that usually has an ulterior motive (Berne 1959: 157; Cornwell et al. 2016: 72). Cornwell et al. (2016: 72-79) give extended details of the different types of covert transactions and how they come into play during communication. I am mainly interested in Berne's classification of this type of transaction as an integral part of what he called a 'game' (Berne 1959: 157). Games are usually part of much larger and complex transactions in which players in their different ego states utilize the various options they have to attain social control (Berne 1959: 158). From my analysis of Berne's development of this concept of games in his 1964 publication, I tend to call this type the transaction of manipulation, which Nzira used to assume and perpetuate a Parent ego state among his members. This type of transaction gave him the option to attain social control as a Parent over his members. This type of transaction was at play in this first case. The explicit message was,

Do not read the Bible because you get nothing from there. These are old stories about other people's engagement with God.

The implicit psychological message was that

When I healed you, you experienced God. God is present in me. 
What I am doing here I am writing the live story about God's engagement with the Africans and therefore, why do you need the Bible?

Four other TA concepts, redefining, discounting, injunctions and drivers, may further clarify my analysis of the transaction between Nzira and his members in this first case. Redefining occurs when a transacting party contaminates ego states through deliberately distorting reality to match their preferred way of seeing the world and thus, choosing to ignore any evidence that would contradict their life script, an unconscious pathway created from childhood and that parents reinforce (Berne 1972: 46). Discounting occurs when a transacting party takes something as of a lesser worth than it is. I argue that this is exactly what Nzira did with the Bible. He redefined and discounted it. He then intensified the discounting through the injunctions and/or drivers of healing rituals and games.

Berne (1972: 139) defined an injunction as a prohibition or negative command from a parent. Budisa and other authors (2012: 29) list several injunctions and argue that a people form their life scripts based on injunctions they receive. In this first case, the injunction not to read the Bible had the effect of perpetuating Nzira's Parent ego state and it became part of the ridiculed man's life script. Nzira enhanced his attainment of social control through the driver of the healing rituals. Drivers are words, tones, speech patterns, gestures, posture, facial expressions, the way people dress and any behaviour to this effect that accounts for a child's introjection of messages from a Parent ego state that a transacting party in Child ego state moves into in response to distress (Davidson \& Mountain n.d.) or, as I call it, deprivation. For quite some time, this man in question had suffered from the deprivation of ill health, and the healing drove him into a Child ego state in which he accepted the injunction from the Parent, Nzira. Nzira conducted several healing ceremonies daily at Juranfiri Santa, and each healing ritual, like this one under analysis, culminated in teaching comprising injunctions about this or that and with the ulterior message that he was in control.

\section{Analysis of Case 2}

On the second occasion Matthew and I visited the shrine and I think that day we were quite early because, although there was a huge crowd already, there 


\section{David Bishau}

was no activity yet. People were just sitting waiting for Nzira to appear. I guess he has a way of hiding himself from people because on that day he just stood up from among the apostolics who were there and started to address them. We were all surprised where he suddenly came from. Even Matthew, who knew him very well, had not recognized him. He started talking in a very low voice with his interpreter, shouting the message out for people to hear. One Mudare sitting next to me explained that the 'angel' who was speaking through Nzira that day was Baba Johanne himself (meaning Shoniwa, Johanne Masowe himself). True to this elder's word, Nzira indicated that he was sent to Africa to deal with cruelty, witchcraft, jealousy among Africans and to solve African problems. Interestingly, he distinguished between ailments that require biomedical solutions and ailments due to mashavi (spirits of the dead that possess people and cause illness) and his mission was to deal with the latter.

Ukakuwara muaccident usauya kuno, enda kuchipatara. Hatirapi zvirerwe zvakadaro kuno. Kuno tinorwisana netsino, utsinye wemunhu mutema. (If you are injured in a road traffic accident, do not come here; go to the hospital. We do not deal with such ailments here. Here we deal with illness caused by spirits and cruel or evil intentions of the Africans.)

This, as I stated earlier, was Johanne Masowe's mission. Nzira was re-enacting that mission and bringing it forth among his people. This makes me bring to attention in this analysis a concept of TA, mythos (plural, mythoi), which Berne (1972: 438) mentions, but did not develop as much as he did the other concepts. I translate the term mythos, as others familiar with Koine Greek do, to mean a myth, but for purposes of this analysis, I do not get into the different detailed definitions of a myth from scholars. I follow Milnes' (2017: 203) definition of a myth as an ancient religious story, because he uses this definition within the context of TA, which is my context too. This translation and definition, though convenient, do not capture everything that the Greek term mythos entails and therefore, in my analysis I will maintain the Greek term.

I will deliberately elaborate on the historical analysis of the presence of the Bible among the Johanne Masowe in order to present my analysis of this second case with some relative clarity. That section of the article tells us the religious story of the legendary birth and call of Johanne Masowe with a definitive mission to deal with evil among the Africans. This story plunges us 
deep into the African, and particularly Shona, mythos. Each culture, country and people in the world has a mythos, which gives valuable insights into how the people in that culture perceive and think about their world and how they order their lived experiences, set standards of behaviour, and shape and reflect on their cultural values (Thornhill 2019, Greek Mythology para. 2.). part of the African mythos is crafted around the world of mashavi (alien spirits) especially, the African belief in $n g o z i$ (avenging spirits). In this mythos, evil spirits possess people and influence them to harness evil natural powers to control and even harm others. However, part of the mythos is that there are benevolent spirits, God or gods or the ancestral spirits, champions, who can exorcise these evil spirits and bring healing among the people. God sent Johanne Masowe as that champion to deal particularly with African health problems. Looked at from the context of TA, this mythos has become part of the Shona's life scripts.

In the healing rituals, Nzira cited the exact words of Johanne Masowe when God gave him the mission to Africa: 'Ndakatumwa kuAfrica kunorwa netsino dzeAfrica' (I was sent to fight with the evil spirits in Africa). Thus, Nzira's healing rituals re-enacted, not only the myth of the birth and call of Johanne Masowe, but also the very core of the African (Shona) mythos. This re-enactment placed him at the centre of the Johanne Masowe WeChishanu belief system, not just as a representative of Johanne Masowe, but also as the living champion of Africans suffering from the deprivation of ill health that evil spirits in Africa cause. That takes us to an analysis of the third case.

\section{Analysis of Case 3}

The third and last incident involved a female leader of a huge group of Johanne Masowe apostolics from Hatcliffe, Harare. I later understood that she once belonged to the Juranfiri Santa congregation under Nzira. She broke away and because of her healing powers and prophetic gift she managed to grow her own Sowe (congregation) in Hatcliffe. In my guess, her members exceeded 2000 just by mere looking. She stood up and started explaining why she had come and Nzira gave her ample time.

Tadzoka kubva kukakiriniki kedu ketakagadzira petakasimuka pano tichimbopambara nenyika. Tati zvekukiriniki hazvina kunyatsa kukwana, saka tati timbouya nevana kuno kuchipatara. (We have come back from the clinic that we introduced when we left this place. 


\section{David Bishau}

We thought services at the clinic may not be adequate and so we had to bring our children here at the hospital for adequate services.)

To analyse this last case, I use the TA concepts of strokes and intimacy as well as the overall philosophy and goal of TA as a communication tool. Strokes are the recognition, attention or responsiveness that one person gives another and how that recognition and attention influence motives (Cornwell et al. 2016: 40). The key idea is that people hunger for recognition, and that lacking positive strokes, will seek whatever kind they can, even if it is recognition of a negative kind. In this third case, we witness Nzira's hunger for recognition and the effect that hunger for recognition dwarfed all other members who may have been equally, if not more talented than him in terms of spiritual gifts. This female leader from Hatcliff failed to break free from the Child ego state and the historical maladaptations embedded in her childhood script like lack of self-confidence and the need always to come back to the parent for vindication. Nzira himself played games in which members exchanged very strong strokes with him but satisfied his covert purposes.

What lacked in Nzira's interaction with this female leader was yet another concept of TA called intimacy. Intimacy is the act of allowing the interaction where one exchanges the strongest strokes in an unconditional and relational manner without any covert purposes. Such kind of interaction is in tandem with the goal and overall philosophy of TA. The goal of TA is for people to gain autonomy from the childhood script by changing their destiny through getting rid of historical maladaptations embedded in that script. This way they become free from undesirable emotion that hinder their justifiable and honest reflection of their present life. We do not see that autonomy in the female leader from Hatcliff who should not have come back to Juranfiri Santa for vindication of her powers and leadership. However, this worked well for Nzira. His game paid the ultimate dividend of attracting the strongest of strokes from his members, which were so strong that he even replaced the Bible from their minds.

\section{Conclusion}

Therefore, is the Bible present or absent among the Johanne Masowe WeChishanu? In this article, I argue that the Bible is present among the Johanne Masowe WeChishanu; only that Madzibaba Nzira, the leader of the 
group, psychologically substituted it in order to maintain a firm grip on his devotees. I use the psychological paradigm of 'transactions' to decipher and provide answers to the critical questions I raised at the beginning regarding the presence or absence of the Bible among the Johanne Masowe WeChishanu. Where there is the presence of a written text, the Bible in this case, then emphasis is on it as a source of authority. Such emphasis would remove attention from Nzira, the celebrated leader of the Johanne Masowe WeChishanu. Through healing rituals, he re-enacted the myth of Johanne Masowe's call and mission to Africa that produced a Parent ego in and around himself through the claim that the spirit of Johanne operated in him and therefore, the Law, let alone, the Bible as a whole, was 'live and direct' in his person. That ideological tactic to shift emphasis from the written text to him granted Nzira not only a lot of power but also lots of authority that resulted in the development of a Child ego within the individual members. He thus became the authority himself. By removing the Bible from the devotees, Nzira manipulated transactions, playing a mind game so that his devotees would never achieve the goal of autonomy; they would never achieve freedom from the childhood script and would continue to depend on him always for spiritual nourishment. Thus, in spiritual matters he would perpetually assume the Parent ego while the devotees would remain passive in the Child ego state. In fact, the net effect of this was to remove God from the devotees and Nzira himself replacing God. I am not surprised that when the police later arrested him in 2003 on charges of rape (Mujinga 2018: 258), his devotees thronged the courtroom chanting a very bizarre maxim, 'You cannot arrest God' (Zimunya \& Gwara 2019: 117). Such is what gullibility does when it reaches certain heights. Therefore, while the Bible may be physically absent, it does not necessarily mean it is not important among the Johanne Masowe.

\section{References}

Adams, A.S. 2008. Using Transactional Analysis and Mental Imagery to Help Shame-Based Identity Adults Make Peace with their Past. ADULTSPAN Journal 7,1: 1-12. https://doi.org/10.1002/j.2161-0029.2008.tb00038.x

Anderson, H. 2001. African Reformation African Initiated Christianity in the $20^{\text {th }}$ Century. Trenton: Africa World Press.

Berne, E. 1957a. Ego States in Psychotherapy. American Journal of Psychotherapy 11: 293-309. 
https://doi.org/10.1176/appi.psychotherapy.1957.11.2.293

Berne, E. 1957b. Intuition V: The Ego Image. Psychiatric Quarterly 31: 611627. https://doi.org/10.1007/BF01568754

Berne, E. 1958. Transactional Analysis: A New and Effective Method of Group Therapy. American Journal of Psychotherapy 12: 735-743.

https://doi.org/10.1176/appi.psychotherapy.1958.12.4.735

Berne, E. 1959. Principles of Transactional Analysis. Indian Journal of Psychiatry 1,4: 215-221.

Berne, E. 1961. Transactional Analysis in Psychotherapy. Auckland: Castle Books.

Berne, E. 1963. The Structure and Dynamics of Organizations and Groups.

Philadelphia: J.B. Lippincott Company.

Berne, E. 1964. Games People Play. New York: Grove Press.

Berne, E. 1975. A Layman's Guide to Psychiatry and Psychoanalysis. New York: Grover Press.

Berne, E. 1975. What Do You Say After You Say Hello? London: Corgi Books. Bishau, D. 2010. Reign with Him for a Thousand Years (Rev. 20:6): A Sociohermeneutical Exposition of Biblical and Contemporary Millenarian Movements as Radical Responses to Deprivation. Bamberg: Bamberg University.

Budisa, D., V. Gavrilov-jerkovic, A. Dickov, N. Vučković \& S.M. Mitrovic 2012. The Presence of Injunctions in Clinical and Non-clinical Populations. International Journal of Transactional Analysis Research 3, 2: 28-36. https://doi.org/10.29044/v3i2p28

Cooke, B. 2019. Transactional Analysis and Ego States. Available at: https://mcpt.co.uk/transactional-analysis-and-ego-states/ (Accessed on 3 February, 2020 at $2205 \mathrm{hrs}$ ).

Cornell, W.F. 2000. If Berne met Winnicott: Transactional Analysis and Relational Analysis. Transactional Analysis Journal 30: 270-275.

https://doi.org/10.1177/036215370003000403

Cornell, F.W., H. Hargaden \& J.R. Allen 2005. From Transactions to Relations: The Emergence of a Relational Tradition in TA. London: Haddon Press Limited.

Cornell, W.F. \& M. Landaiche 2006. Impasse and Intimacy: Applying Berne's Concept of Script Protocol. Transactional Analysis Journal 36, 3: 196 213. https://doi.org/10.1177/036215370603600304

Cornell, F.W., A. de Graaf, T. Newton \& M. Thunnissen 2016. Transaction. In 
Cornwell F.W., A. de Graaf, T. Newton \& M. Thunnissen (eds.): Into TA: A Comprehensive Textbook on Transactional Analysis. London: Karnac Books Ltd.

Cornell, W. 2020. Transactional Analysis and Psychoanalysis: Overcoming the Narcissism of Small Differences in the Shadow of Eric Berne

Transactional Analysis Journal 50, 4: 1 - 15.

https://doi.org/10.1080/03621537.2020.1771020

Davidson, C. \& A. Mountain n.d. The Psychology of Relationships.

Available at: https://www.businessballs.com/building-

relationships/transac tional-analysis-eric-berne/

(Accessed on 2 February, 2020 at 1622hrs.)

Dillon-Malone, C. 1987. Gospel of God VaPositori VaJohane Masowe.

Lusaka: Teresianum Press.

Engelke, M. 2004. Text and Performance in an African Church: The Book, 'Live and Direct'. The American Ethnologist 31,1: 76-91.

https://doi.org/10.1525/ae.2004.31.1.76

Fairbairn, W.R.D. 1952b. A Revised Psychoanalysis of Psychoses and Psychoneurosis. In Psychoanalytic Study of the Personality. London: Routledge and Kegan Paul.

Federn, P. 1952. The Ego as a Subject and Object of Narcissism. In Weiss, E. (ed.): Ego Psychology and Psychoses. New York: Basic Books.

https://doi.org/10.1037/10571-000

Heathcote, A. 2010. Eric Berne's Development of Ego-State Theory: Where did it all Begin and Who Influenced Him? Transactional Analysis Journal. 40, 3: 254 - 260.

https://doi.org/10.1177/036215371004000310

Izwi RaMwari KuAfrica [1932] n.d.

Kileff, C. \& M. Kileff 1979. The Masowe VaPositori of Seki Utopianism and Tradition. In Jules-Rosette B. (ed.): New Religions of Africa. San Diego: University of California.

Lapworth, P. \& C. Sills 2011. An Introduction to Transactional Analysis. Los Angeles: SAGE. https://doi.org/10.4135/9781473957763

Maguranyanga, B. 2011. Apostolic Religion, Health and Utilization of Maternal and Child Health Services in Zimbabwe. Harare: CCORE.

Martin, C.H. 2011. Transactional Analysis: A Method of Analysing Communication. British Journal of Midwifery 19, 9:587 - 593. https://doi.org/10.12968/bjom.2011.19.9.587 
Melwin, J.M. 2014. Structural Analysis - Transactional Analysis. Available at: https://www.slideshare.net/manumjoy/the-ego-state-model

(Accessed on 2 February, 2020 at 1935hrs).

Milnes, P. 2017. The Pilgrim Model. Transactional Analysis Journal 47, 3: 203 - 217. https://doi.org/10.1177/0362153717711698

Morad, N. 2018. How to Use Psychology to Communicate Better and Avoid Conflict. https://medium.com/@NataliMorad/how-to-communicatebetter-with-transactional-analysis-d0d32f9d50da

(Accessed on 2 February 2020 at 2020hrs.)

Mujinga, M. 2018. 'Religion as a Riding Horse of Politics'. A Critical Analysis of Political Influence in the Zimbabwean Ecclesiastical Life. Alternation Special Edition 23: 244-265.

https://doi.org/10.29086/2519-5476/2018/sp23a11

Musoni, P. \& P. Gundani 2016. Easter Celebrations with a Difference: A

Critical Study of the Johane Masowe Chishanu yeNyeyedzi Approach to the Event. Studia Historiae Ecclesiasticae 1-14.

https://doi.org/10.17159/2412-4265/2016/422

Musoni, P. \& P. Gundani 2019. Open Space Worship: A Religious Identity of Johanne. Journal for the Study of Religion 32, 2: 1 - 13.

https://doi.org/10.17159/2413-3027/2019/v32n2a4

Negi, A. 2010. Industrial Psychology. Luchnow: Word Press.

Sundkler, B. \& C. Steed 2000. A History of the Church in Africa. London:

Cambridge University Press.

https://doi.org/10.1017/CBO9780511497377

Thornhill, P.J.R. 2019. Greek Mythology. Available at:

https://www.britannica. com/topic/Greek-mythology

(Accessed on 10 February, 2020 at 2013hrs.)

https://doi.org/10.17583/remie.2020.5182

Tudor, K. (ed.). 2002. Ego States. London: Sage.

White, T. 2000. New Ways in Transactional Analysis. Second Edition. North Perth: TA Books.

Widdowson, M. 2016. Transactional Analysis for Depression: A Step-By-Step Treatment Manual. London: Routledge.

https://doi.org/10.4324/9781315746630

Weiss, E. 1950. Principles of Psychodynamics. New York: Grune and Stratton. Zimunya, T.C. \& J. Gwara 2019. 'Do not touch my anointed!' - An Analysis of Sexual Violations in Zimbabwe's Religious Movements. In Kügler, J., 
R. Gabaitse \& J. Stiebert (eds.): The Bible and Gender Troubles in Africa. Bamberg: University of Bamberg Press.

\section{Interviews}

Mr Chikanya (First Names not given). Interview, conducted by Joshua Mbeu Gandanzara. Mr. Chikanya is a preacher who is now based in Marondera. Madzibaba E. Mundonga. 10 March, 2005, Interview, Mutare.

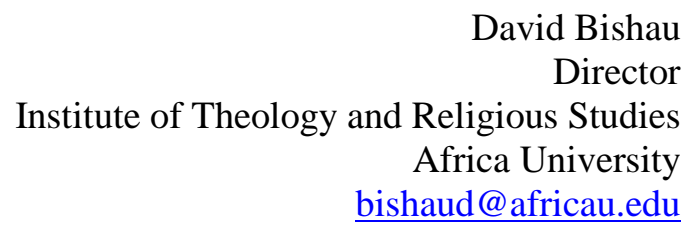

